\title{
THE SO-CALLED PRAYERS OF THE KATHISMATA. BRIEF HISTORICAL-LITURGICAL PRESENTATION
}

\author{
PhD Nicolae PREDA, \\ Faculty of Orthodox Theology „Justinian the Patriarch”, University of Bucharest, \\ ROMANIA, \\ E-mail: preda_nicolae@hotmail.com
}

\begin{abstract}
The habit of reading the so-called "prayers of the Kathismata" is, according to Cyril Korolevsky, one of the most ancient and monastic tradition (which was first encountered at the anchorites) of our Church. Named prayers of the Kathismata (or "prayers of the antiphons", as in the Constantinopolitan tradition), these prayers had different structures depending on the two deterministic liturgical traditions, from Jerusalem and from Constantinople, which is why we will try to render some of their characteristic features.
\end{abstract}

Keywords: Psalter; prayers; liturgical manuscripts; anchorites; monastic tradition; liturgical provinces;

\section{THE LITURGICAL PSALTER - GENERAL SPECIFICATIONS}

Regarding the moment of introduction into the cult and the usage of the so-called "Liturgical Psalter",, unfortunately, the specialized studies do not speak very much; the reason is obvious: the first "prayers" $\left(\text { hymns }{ }^{2}\right)^{3}$ used in worship were, without a doubt, The Psalms of David". Mentions, on the one hand, on the existence of the "Psalms of David"

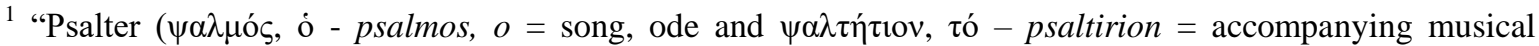

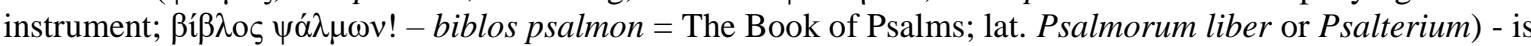
one of the Old Testament books that constituted the first form of singing in Christian cult. Singing of psalms alternated with Bible readings...", Fr. Prof. PhD E. Branişte and Prof. Ecaterina Branişte, Dicţionar enciclopedic de cunoștințe religioase (Encyclopaedic Dictionary of Religious Knowledge), Caransebeş, Diocesan Publishing, 2001, p. 399.

2 "The first testimony showing us a hymn of the Great Entrance of Constantinople, Eutyches homily, speaks of a «Psalmian hymn» and it seems to refer to Psalm 23", cf. R. F. Taft, O Istorie a Liturghiei Sfântului Ioan Gură de Aur. Volumul II. Transferul darurilor și celelalte rituri preanaforale. Partea 1. Intrarea cea Mare (A History of the Divine Liturgy of Saint John Chrysostom. Volume II. Transfer of Gifts and Other Preanaphoral Rites, Part 1. The Great Entrance). $2^{\text {nd }}$ Edition Revised. Translation and preface by Cezar Login, Cluj-Napoca, Renașterea Publishing, 2014, p. 190.

3 "Qualche tipo di salmodia era un elemento del culto cristiano fin dal suo inizio, come è chiaro da molti testi del Nuovo Testamento: 1 Cor 14:26, Ef 5:18-20, Col 3:16-17, Gc 5:13, Ap 5:8-9. Ciò che questi testi intendono esattamente con «salmi, salmodia, cantici» resta comunque dubbio, nonostante l'esegesi a cui questi testi sono tradizionalmente soggetti. Si riferiscono a salmi biblici? Forse, ma non sicuramente", R. F. Taft, A partire dalla liturgia. Perché è la liturgia che fa la Chiesa, Roma, Edizioni Lipa, 2004, pp. 164-165.

4 "Il termine greco $\psi \alpha \lambda \mu$ ó $\varsigma$ non era il solo che i cristiani usavano per i salmi di Davide, né questo termine per se si limitava ai salmi biblici. E sebbene l'uso dei primi cristiani sembri favorire l'interpretazione del termine in riferimento ai salmi biblici, dove non ci sono ragioni di sospettare un altro significato, fino al III-IV secolo vediamo autori latini e greci che usano ancora $\psi \alpha \lambda \mu$ ó $/$ psalmus in riferimento a composizioni chiaramente non bibliche. Ma poiché numerosi testi del Nuovo Testamento si riferiscono al canto di un tipo o di un altro, e poiché in questo tempo $\psi \alpha \lambda \mu o$ er era diventato per gli ebrei ellenofoni il nome proprio greco di ciò che
} 
within worship, and on the other, of the so-called "prayers of the Kathismata", we find recorded in Canon 17 of the Synod $^{5}$ of Laodicea $(364)^{6}$, where it is remembered (commanded) "the psalms of David should not be read all at once, in the congregations and the ministry of the church, lest the crowd be bored for their length, and that they should come out of the church. But among the psalms should be read prayers, so that the people may rest a little..." . An interesting phrase, which seems to render another dimension of the perception of David's Psalms in worship, and which combines two relatively identical concepts (hymn and psalm), namely, "the psalmian hymn", belongs to the Patriarch Eutychius of Constantinople (552-565, 577-582), and we find it in a word spoken at Easter (Sermo de Paschate et de sacrosancta Eucharistia): "Those who have taught the people to

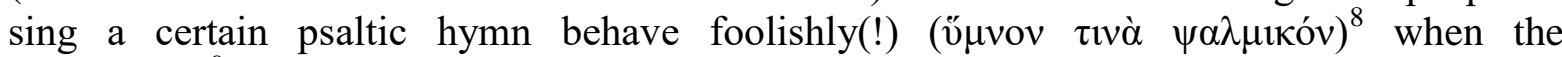
ministers...", this "psaltic hymn", otherwise a hymn of ("antiphon") the Great Entrance, "is, apparently, referring to Psalm 23"10.

\section{THE BYZANTINE LITURGICAL PSALTER - SPECIFIC FEATURES}

The Byzantine Liturgical Psalter, whether it is the one in use at Jerusalem ${ }^{11}$, or in Constantinople $^{12}$ (called, due to its mobility, also "The Distributed Psalter"13), different, actually, from the Biblical Psalter (less accurate name, according to Fr. R. Taft ${ }^{14}$ ), was divided into 60 "stops" ( $\sigma \tau \dot{\alpha} \sigma \varepsilon l \varsigma))^{15}$ and 20 "kathismata" $\left.(\kappa \alpha \theta i \sigma \mu \alpha \tau \alpha)\right)^{16}$, according to the

conosciamo come i salmi di Davide (sebbene non esclusivamente), non contesterò, né tenterò di provare il giudizio comune secondo il quale i primi cristiani usavano probabilmente i salmi biblici nei loro raduni. $\mathrm{E}$ perfettamente chiaro che alla fine i cristiani giunsero a fare cosí, ed è ugualmente ovvio che essi presero questi salmi dal giudaismo", R. F. Taft, A partire dalla liturgia..., p. 165; see also R. F. Taft, A partire dalla liturgia..., p. 165, notes 7, 8 and 9 .

5 “Synod (lat. concilium, sinodus; gr. $\sigma u ́ v o \delta o \varsigma, \dot{\eta}-$ sinodos = gathering) - within the Church, is the gathering of the bishops (hierarchs) in order to discuss its specific problems...”, Fr. Prof. PhD E. Branişte and Prof. Ecaterina Branişte, Dicţionar enciclopedic... (Encyclopaedic Dictionary...), p. 456.

6 "Canon 17: It is not appropriate to huddle together the psalms in gatherings, but among psalms let them read”, Pidalion (reprinted), Neamţ Monastery, 1844, p. 318.

${ }^{7}$ Ibidem, p. 318.

${ }^{8} P G 86^{2}, 2401 \mathrm{~A}$.

${ }^{9}$ R. F. Taft, O Istorie a Liturghiei Sfântului Ioan Gură de Aur... (A History of the Divine Liturgy of Saint John Chrysostom...), p. 146.

${ }^{10}$ Ibidem, pp. 189-190.

11 J. Mateos, "Office de minuit et office du matin chez S. Athanase", in Orientalia Christiana Periodica 28 (1962), p. 175; R. Taft, "Mount Athos: A Late Chapter in the History of the 'Byzantine Rite'", in Dumbarton Oaks Papers 42 (1988), p. 181.

12 M. Arranz, "Les grandes étapes de la Liturgie Byzantine: Palestine-Byzance-Russie: Essai d'aperçu historique", in Liturgie de l'église particulière et liturgie de l'église universelle, Bibliotheca Ephemerides Liturgicae Subsidia 7, Roma, Centro Liturgico Vincenziano-Ed. liturgiche, 1976, p. 50.

${ }^{13}$ O. Strunk, "The Byzantine Office at Hagia Sophia”, in Dumbarton Oaks Papers 9-10 (1956), pp. $200-202$.

${ }^{14}$ R. Taft, "Mount Athos...", p. 181.

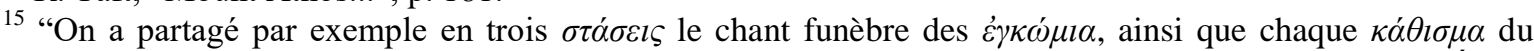

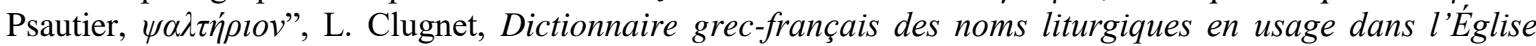
grecque, Paris, A. Picard et fils, 1895, p. 139; R. Taft, "Mount Athos...", p. 182; M. Arranz, "Les grandes étapes...", pp. 57-58.

16 "Kathismata - are called the 20 groups in which the 150 Psalms of David are divided into in the divine Orthodox cult. The kathismata are composed of verses of thematically related psalms (morning or night psalms, etc.)...”, Fr. Prof. PhD E. Branişte and Prof. Ecaterina Branişte, Diç̧ionar enciclopedic...

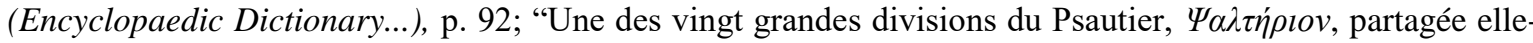

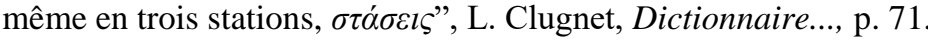




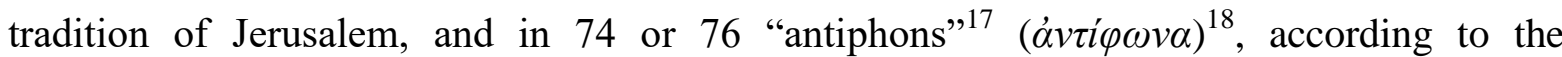
Constantinopolitan usage. Also, the odes ${ }^{19}$ (Biblical songs) ${ }^{20}$ but also the so-called "prayers of the kathismata" (usually placed after the 20 "kathismata" 21 of the Psalter $\left.{ }^{22}\right)^{23}$ had different structures, according to the two liturgical traditions mentioned above, in the sense that in Jerusalem were used nine biblical songs and in Constantinople, fifteen ${ }^{24}$.

\section{THE SO-CALLED "PRAYERS OF THE KATHISMATA" - OVERVIEW}

Among the prayers through which the Church has always been used to pray, there are the so-called "prayers of the Kathismata",25, some of them remained in use until today, within the Vespers' service united with Liturgy ${ }^{26}$ of the Presanctified Gifts ${ }^{27}$, but also the "sacerdotal" or "priestly" prayers (that is, those intended to be read only by the priest), specific, exclusively to the well-known "sung service" (asmatike akolouthia $\left.{ }^{28}\right)^{29}$, at the Great Church (Hagia Sophia) in Constantinople.

17 The connotation of the word "antiphon" (in Greek, $\alpha v \tau i \varphi \omega v o v$ ) in this context is a specific one, and designates a group of two or more Psalms; unfortunately, this connotation does not compare in dictionaries [see for example, Fr. Prof. PhD E. Branişte and Prof. Ecaterina Branişte, Dicţionar enciclopedic (Encyclopaedic Dictionary...), pp. 37-38]; "In Constantinople the Psalter itself was divided into antiphons, each comprising, in principle, three psalms having the same antiphon-chorus...", J. Mateos, Celebrarea cuvântului în Liturghia bizantină. Studiu istoric (Celebrating the Word in Byzantine Liturgy. Historical Study). Translation and notes by Cezar Login, Cluj-Napoca, Renaşterea Publishing, 2007, pp. 8-9, note 23.

${ }^{18}$ R. Taft, "Mount Athos...", p. 181.

19 “(da odái = canti): nel rito bizantino sono: 1. i canti scritturali dell’Orthrós; 2. il complesso dei tropari poetici del canone", D. Sartore, A. M. Triacca and C. Cibien, Liturgia, Milano, Edizioni San Paolo, 2001, p. 2116.

${ }^{20}$ R. Taft, "Mount Athos...", p. 181; M. Arranz, "L’office de l'Asmatikos Orthros («matines chantées») de l'ancien Euchologe byzantin", in Orientalia Christiana Periodica 47 (1981), pp. 140-141.

${ }^{21}$ The Byzantine Liturgical Psalter, that is, the one that is today in use [cf. Psalter of the Prophet and Emperor David, Bucharest, Publishing House of the Bible and Mission Institute of the Romanian Orthodox Church, 2016)], records 20 prayers (one prayer after each kathisma); in regard to the prayers of the so-called Constantinopolitan Psalter, we know, as indicated in the colophon of the famous codex Coislin 213 ["Euchologium Strategii presbyteri. (a. 1027)", cf. H. Omont, Inventaire sommaire des manuscrits grecs de la Bibliothèque nationale, Troisième partie: Ancien fonds grec, codd. 2542-3117. Coislin. Supplément grec. Autres bibliothèques de Paris. Départements, Paris, Libraire Alphonse Picard, 1888, p. 150], that in Constantinople there was also a specific book that contained "prayers of the antiphons" of the Psalter (74 prayers of the antiphons; 8 ofthe Odes and 54 other different prayers), which a certain "prezbiter Strategios" had in possession (unfortunately, this collection of prayers has not yet been discovered).

22 "And this is the cause, for which the Divine Fathers divided the Psaltery into 20 kathismata, and among the kathismata they put troparions and prayers. Which are in many Psalters, both in manuscripts, and printed", Pidalion, p. 318.

${ }^{23}$ M. Arranz, "Les prières presbytérales des matines byzantines $-2^{\text {de }}$ partie: Les manuscrits", in Orientalia Christiana Periodica 38 (1972), pp. 66, 86-87.

${ }^{24}$ R. Taft, "Mount Athos...", p. 181, note 19.

${ }^{25}$ M. Arranz, "Les prières presbytérales des matines...”, pp. 86-87.

26 "Messa dei presantificati: nel rito bizantino si dice m. d. p. la liturgia dei giorni quaresimali; in essi infatti si consuma il pane eucaristico consacrato in una precedente celebrazione", D. Sartore, A. M. Triacca and C. Cibien, Liturgia..., p. 2115.

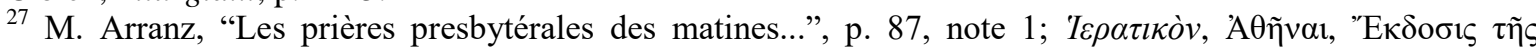

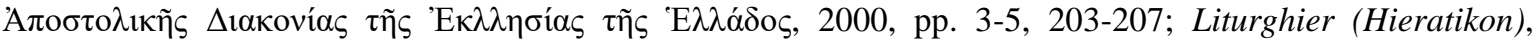
Bucharest, Publishing House of the Bible and Mission Institute of the Romanian Orthodox Church, 2000, pp. 265-272.

28 "asmaticòs, ufficio è l'antica ufficiatura propria delle cattedrali contrapposta a quella monastica che ha finito con il prevalere", Piccolo glossario dei termini liturgici bizantini, cf. http://www.webalice.it/giovanni.fabriani/glossario/glossarioa.htm (web page accessed on January 18, 2015); 
Pr. M. Arranz says, among other things, that many of the "sacerdotal prayers" would have remained in the cult to this day; he speaks about, of course, the prayers of Vespers ${ }^{30}$ and Matins ${ }^{31}$, which the priest reads secretly, while the church singer utters the beginning psalms, within these services ${ }^{32}$.

It is worth mentioning that these "sacerdotal prayers" 33,34 , also known as "priestly prayers" or "presidential prayers" 35 , once read throughout the service, represent, in the opinion of the specialists, a "general feature of the Studite ordinances"36: "the priestly prayers $^{37}$ from Vespers ${ }^{38}$ and Matins ${ }^{39}$, taken from the "singing ordinance - asmatikon(!)

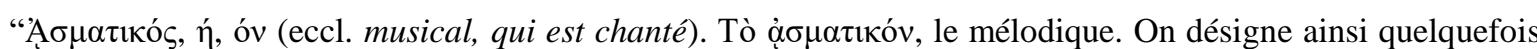
le $\tau$ pı́ó $\gamma ı v$, lorsqu'il est chanté", L. Clugnet, Dictionnaire..., p. 22.

${ }^{29}$ M. Arranz, "Les grandes étapes...", p. 51.

30 "The prayers the priest reads secretly, in front of the royal doors, are called prayers of Vespers, or of the

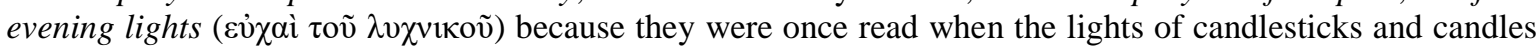
were lit up in the churches to dispel the darkness of the night...”, Fr. Prof. PhD E. Branişte, Liturgica Specială pentru institutele teologice (Special Liturgy for Theological Institutes), Bucharest, Publishing House of the Bible and Mission Institute of the Romanian Orthodox Church, $1985^{2}$, p. 66.

31 "The 12 prayers read secretly by the priest during the six psalms, Morning prayers or of Matins, have varied content...", Ibidem, p. 139.

32 "Les grandes étapes...", p. 51.

33 “3.2.7. Preghiere. Costituiscono un elemento importante dell'ufficiatura bizantina, specialmente quelle presbiterali dell'orthros e del vespro; parecchie sono anonime e quelle che hanno nome di autore sono di difficile attribuzione", M. Nin, Ufficiatura bizantina. La Liturgia delle ore nella tradizione bizantina, Roma, Dispense Pontificio Istituto Orientale, 2002-2003, p. 20.

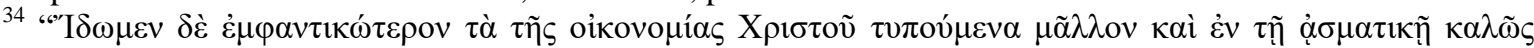

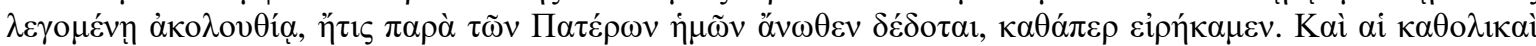

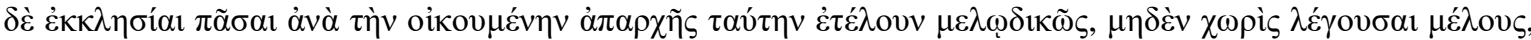

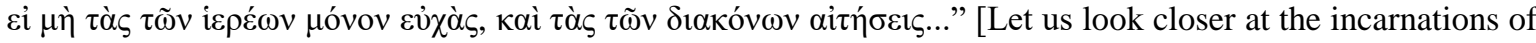
Christ, imagined especially in the service called of the songs. This service was given, as we have said before, by our Fathers. All the churches in the world commemorate these in verses, they say nothing without verses, except the prayers of the priests and the deacons' readings...], $P G 155$, p. 624C; see also N. Borgia, Horologion. Diurno delle chiese di rito bizantino, in Orientalia Christiana 56 = 16/I, Roma, Pontificio Istituto Orientale, 1929, p. 171.

35 "Nelle preghiere presidenziali dell'asmatikòs il culto della gloria divina è anzitutto un'azione di grazie a Dio che prende egli stesso l'iniziativa di chiamare l'uomo alla preghiera", Il Signore della gloria. Preghiere della "Grande Chiesa" bizantina. Traduzione e note di Stefano L. Parenti, Milano, Edizioni Paoline, 1988, p. 134.

36 Hierom. PhD Petru Pruteanu, "Evoluţia Rânduielilor tipiconale în Răsăritul ortodox. Studiu istorico liturgic" (The Evolution of the Typikon in the Orthodox East. Liturgical Historical Study), in Studii Teologice, Third Series, Year II, No. 1 (2006), p. 90; see also page 90, note 95.

37 "Le sette preghiere recitate dal sacerdote davanti all'iconostasi sono di origine costantinopolitano e risalgono almeno al VIII secolo", M. Nin, Ufficiatura bizantina..., p. 38; see also M. Arranz, "Les prières sacerdotales des vêpres byzantines", in Orientalia Christiana Periodica 37 (1971), pp. 85-124; "Durante i tre ultimi salmi, il sacerdote recita le 12 preghiere sacerdotali mattutine, che sono di tradizione costantinopolitana e le troviamo in uno degli eucologi più antichi, quello Barberini 336 ( $8^{\text {th }}-9^{\text {th }}$ centuries)", M. Nin, Ufficiatura bizantina..., p. 24.

38 “p. es. una preghiera vespertina dell'asmatikòs si trova ora nella "Grande Compieta” (!). (Cfr. Hôrologion, Roma 1937, 256)", Il Signore della gloria..., p. 137, note 102; one of the old prayers of Vespers is today in the order of the Great Compline; it's the prayer "Lord, Lord, Who has delivered us from the whole arrow..."

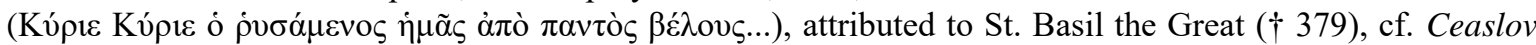
(Horologion), Bucharest, Publishing House of the Bible and Mission Institute of the Romanian Orthodox Church, 2001, p. 179, which will "survive" in the order of the "Kneeling Vespers of Pentecost", cf. Molitfelnic cuprinzând Slujbe, Rânduieli şi Rugăciuni săvârşite de preot la diferite trebuinţe din viaţa creștinilor (Euchologion including Services, Ordinances and Prayer spoken by the Priests on Various Necessities from the Life of Christians), Bucharest, Publishing House of the Bible and Mission Institute of the 
akolouthia", were not read all at once as they were now, but they were distributed throughout the service ${ }^{40,41}$. We also note that some of these old "sacerdotal prayers" have "become", if we can express in this way, also "prayers of the Kathismata", and can be read by faithful ${ }^{42}$; as to the manner in which this change had taken place and the meaning in which it had taken place, it's hard to say; it would be interesting for those passionate about this type of evolution of the structures of worship to deepen one day these aspects.

As for the number of the "sacerdotal prayers" of the well-known "sung service" (asmatike akolouthia), called also "prayers of the Antiphons ${ }^{43}$ of the Psalter" ${ }^{44}$, this is known thanks to the colophon ${ }^{45}$ of the famous codex Coisl. 213 [Euchologion, a. 1027] ${ }^{46}$; these prayers would disappear, little by little, from the Prayer Books ${ }^{47}$ recently drafted, in so far as the so-called "sung service" would give their place to the monastic services of

Romanian Orthodox Church, 2006, p. 708; see also M. Arranz, L'Eucologio Costantinopolitano agli inizi del secolo XI. Hagiasmatarion \& Archieraticon (Rituale \& Pontificale) con l'aggiunta del Leiturgikon (Messale), Roma, Editrice Pontificia Università Gregoriana, 1996, pp. 71-72, 119-120.

39 "En premier lieu, il s'agit des synapties et des prières presbytérales qui trouvaient place ici et là dans les vêpres et les matines", Thomas Pott, Réforme monastique et évolution liturgique. La réforme stoudite, in Crossroad of cultures. Studies in Liturgy and Patristics in Honor of Gabriele Winkler, edited by Hans-Jürgen Feulner, Elena Velkovska and Robert F. Taft, in Orientalia Christiana Analecta 260, Roma, Pontificio Istituto Orientale, 2000, p. 574 and Thomas Pott, La réforme liturgique byzantine. Étude du phénomène de l'évolution non-spontanée de la liturgie byzantine, in Bibliotheca Ephemerides Liturgicae Subsidia 104, Roma, Centro Liturgico Vincenziano - Edizioni Liturgiche, 2000, p. 115.

40 "In questo tipo di preghiera oraria, grazie alla sintesi operata dai monaci studiti, sono sopravvisuti alcuni elementi dell' antico asmatikòs e con essi circa venti delle sue preghiere presidenziali che però vengono recitate a voce bassa (!) una dietro l'altra (!), parte durante la declamazione del salmo introduttorio del vespro e parte durante la salmodia notturna del mattutino se non confinate in altri uffici, così che queste preghiere, composte per essere ascoltate da tutti, vengono ora clericalmente liquidate in una recita spesso frettolosa", Il Signore della gloria..., pp. 136-137.

${ }^{41}$ M. Arranz, "Le sacerdoce ministériel dans les prières secrètes des Vêpres et des Matines byzantines", in Euntes docete XXIV (1971), p. 192.

${ }^{42}$ See the so-called prayer of the "Bending of heads" at the end of the Matins: Holy God, Who in those of the above... and "The Prayer before the Gospel", at the Divine Liturgy: Shine in our hearts... (sacerdotal prayers par excellence), cf. Liturghier cuprinzând Vecernia, Utrenia, Dumnezeieștile Litughii ale Sfinților: Ioan Gură de Aur, Vasile cel Mare, Grigorie Dialogul (a Darurilor mai înainte Sfințite), Rânduiala Sfintei Împărtășiri și alte rugăciuni de trebuință (Hieratikon including Vespers, Matins, Divine Liturgies of Saints: John Chrysostom, Basil the Great, Gregory the Dialogue (of the Presanctified Gifts), the Order of Holy Communion and other necessary prayers), Bucharest, Publishing House of the Bible and Mission Institute of the Romanian Orthodox Church, 2012, pp. 102 and 147-148; these prayers are also found among the socalled "prayers of the Kathismata" from the current Psalter (which can also be read by believers), cf. Psaltirea Prorocului și Împăratului David (Psalter of the Prophet and Emperor David), Bucharest, 2016, pp. 184 and 160.

${ }^{43}$ See the connotation of the word "antiphon" in this context, in the notes above.

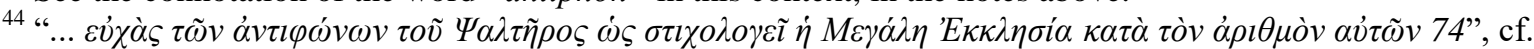
M. Arranz, L'Eucologio Costantinopolitano..., p. 13.

45 "Colophon s.n. Note at the end of a book in the age of manuscripts and incunabula, including data on the printer, the place where he worked, the author and the title of the work", cf. https://dexonline.ro/definitie/colofon (web page accessed on January 27, 2017).

46 "Euchologium Strategii presbyteri (a. 1027)", H. Omont, Inventaire sommaire des manuscrits grecs de la Bibliothèque nationale, Troisième partie: Ancien fonds grec, codd. 2542-3117. Coislin. Supplément grec. Autres bibliothèques de Paris. Départements, Paris, Libraire Alphonse Picard, 1888, p. 150.

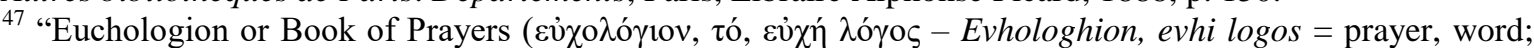
from $\varepsilon \dot{\lambda} \lambda \sigma \gamma \tilde{\omega}-e v \log o=$ to bless) - is the liturgical book which includes all the services required by the Christian's spiritual needs from birth to death...”, Fr. Prof. PhD E. Branişte and Prof. Ecaterina Branişte, Dicţionar enciclopedic... (Encyclopaedic Dictionary...), p. 309. 
Horologion $^{48}$ (Book of Hours) ${ }^{49}$. Moreover, even the Psalter of Palestinian type itself would become the Byzantine Monastic Psalter, and it would be imposed in practice, which is confirmed by the current liturgical use ${ }^{50}$.

We also want to emphasize the original number of the so-called "prayers of the Kathismata", that we do not have a clear answer yet, in the sense that it is not known if their original (exact) number would have been $20^{51}$ (one after each "Kathisma") ${ }^{52}$, as in the current practice, 60 (three after each "Kathisma") ${ }^{53}$ or 74 , like those "of the antiphons of the Psalter in the use 54 of the Great Church".

Moreover, some "Liturgical Psalters" render, after certain Kathisma, not only three prayers, but two $^{55}$ or four ${ }^{56}$, as it can be seen in the manuscripts Ateniense $2478^{57}$ and Vindobonensis Theol. gr. $177^{58}$. According to an "Appendix" ("Appendix D5: Prayers Found in Psalters and Horologia") ${ }^{59}$ of G. Parpulov's study, it would be no less than 30 pages of

48 “'L'Horologhion, il libro liturgico dell’Ufficio bizantino, ha queste ore: mezzanotte (mesonicticon), mattino (òrthros), prima, terza, sesta, nona vespro (esperìnon o lychnicon), compieta (apòdeipnon)", D. Sartore, A. M. Triacca and C. Cibien, Liturgia..., p. 1061.

${ }^{49}$ M. Arranz, "Les grandes étapes...", p. 51.

${ }^{50}$ R. Taft, "Mount Athos...", p. 182; M. Nin, Ufficiatura bizantina..., p. 17.

${ }^{51}$ See Vatican gr. 778 [“4 <Psalterium continuatum>, nempe psalmi et cantica, saec. XIV”, cf. R. Devreesse, Codices Vaticani Graeci (604-866), t. III, Roma, In Bibliotheca Vaticana, 1950, p. 293].

${ }^{52}$ M. Arranz, "Les prières presbytérales des matines...”, p. 86; Georgi R. Parpulov mentions, among other things, the first Psalters that noted prayers "to every Kathisma", cf. Toward a History of Byzantine Psalters, ca. 850-1350 AD, Plovdiv, 2014, p. 103.

53 “...en raison d'une prière par kathisma en règle générale, ou trois si on sépare les trois doxai de chaque kathisma", M. Arranz, "Les prières presbytérales des matines...", pp. 86-87; in reality, the three prayers are rendered together at the end of the Kathisma [see Ateniense 2478: 12r-15v etc., cf. N. Preda, Aşa-numitele "rugăciuni ale catismelor" potrivit Codicelui Ateniense 2478: studiu de liturgică (The So-called "Prayers of the Kathismata” according to Codex Ateniense 2478: Liturgical Study). Degree Paper, Bucharest, Granada Publishing, 2016, pp. 37-41 and Vindobonensis Theol. gr. 177: 27r-29v etc.].

54 "degli antifoni del Salterio come le usa la Grande Chiesa", cf. J. Duncan, Coislin 213. Euchologe de la Grande Église, Roma, Dissertatio ad Lauream Pontificio Istituto Orientale, 1983, p. VII; the underlined phrase has been translated in this manner by J. Duncan (see the previous reference), although the original Greek uses the verb " $\sigma \tau \imath \chi 0 \lambda \mathrm{o} \gamma \varepsilon \tilde{\imath}$ " = recite.

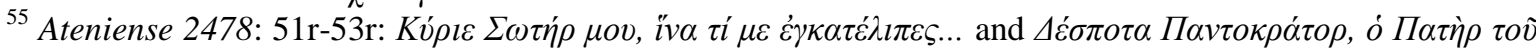

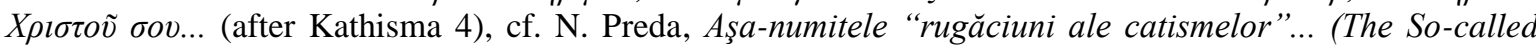

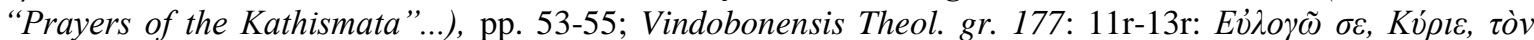

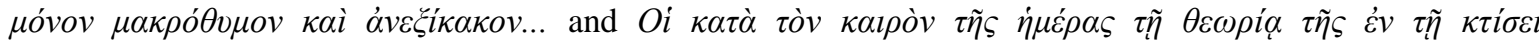
$\mu \varepsilon \gamma \alpha \lambda$ ovp $\gamma i \alpha \varsigma . .$. (after Kathisma 1).

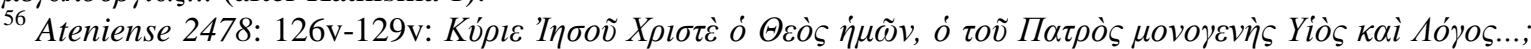

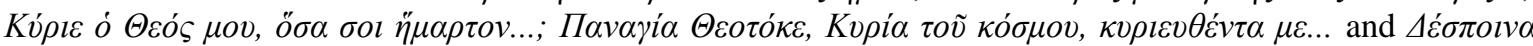

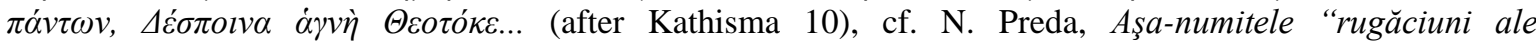
catismelor"... (The So-called "Prayers of the Kathismata"), pp. 76-80; Vindobonensis Theol. gr. 177: 18r-

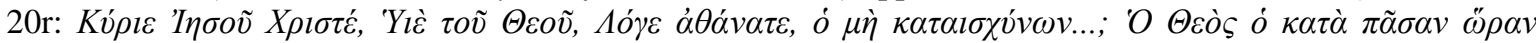

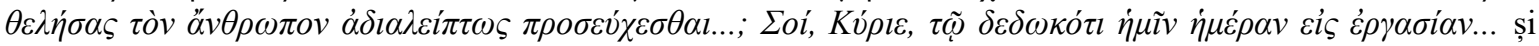

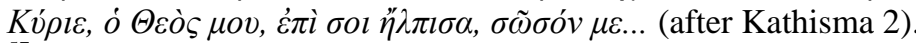

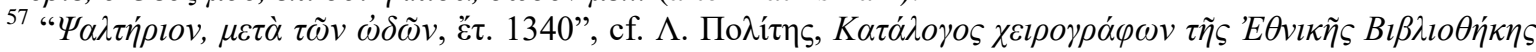

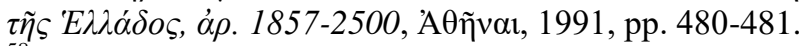

58 "PSALMEN UND ODEN, a. 1150", cf. Herbert Hunger, Otto Kresten und Christian Hannick, Katalog der griechischen Handschriften der Österreichischen Nationalbibliothek, Teil 3/2. Codices Theologici 101-200 [Museion. Veröffentlichungen der Österreichischen Nationalbibliothek. Neue Folge herausgegeben von der Generaldirektion. Vierte Reihe: Veröffentlichungen der Handschriftensammlung. Erster Band, Teil 3/2], Wien, Hollinek, 1984, p. 316.

${ }^{59}$ Toward a History of Byzantine Psalters..., p. 182. 
incipits $^{60}$ (cca 412 prayers, with the ones mentioned, it is true, also in Horologion ${ }^{61}$ ) of the so-called "prayers of the Kathismata"62.

G. Parpulov also provides one of the important information on "prayers of the Kathismata" şi anume, că nu vor fi consemnate în codice mai devreme de sec. al XII-lea (namely 1105 , when is dated the manuscript Harvard gr. $\left.3^{63}\right)^{64}$, although in practice we already have clues in the 9th century, at St. Athanasia of Aegina ${ }^{65}$ :

"These are the oldest Psalters with short hymns (troparia) 66 and prayers introduced to every kathisma, for example after the Psalms 8, 16, 23, etc. Harv. $3^{67}$ is dated, according to the contents of a paschal list, in the year 1104; Iber. $22^{68}$ and Pantokr. $43^{69}$ are written in a very similar style and must have been copied about the same time"

G. Parpulov's information seems to be fair, since we find "prayers of the Kathismata" also in a codex from the National Library in Vienna dated in the 12th century, which I have already mentioned (Vindobonensis Theol. gr. 177, a. 1150).

a) after Psalm 8 (two prayers):

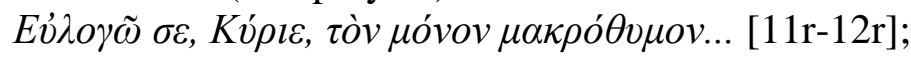

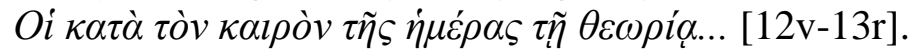

b) after Psalm 16 (four prayers):

Kó

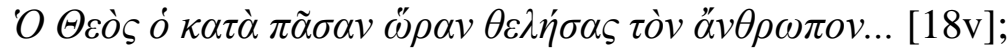

\footnotetext{
${ }^{60}$ The word "incipit" also means, among other things, the first words with which a text actually begins (in this case a prayer).

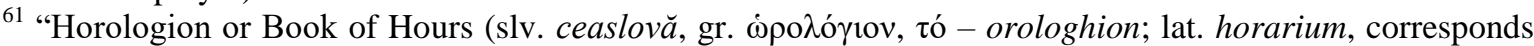
to the book Breviarium, to Catholics) - is one of the liturgical books of the Orthodox Church. Numele de Horologion or Book of Hours (schedule) comes from explaining the time when the services of the seven Church Prayers that form the contents of this book take place...", Fr. Prof. PhD E. Branişte and Prof. Ecaterina Braniște, Dicţionar enciclopedic... (Encyclopaedic Dictionary...), p. 97.

${ }^{62}$ Toward a History of Byzantine Psalters..., pp. 182-211.

${ }^{63}$ Cf. J. Anderson \& S. Parenti, A Byzantine Liturgical Psalter of AD 1105 (Washington [forthcoming]), see Georgi R. Parpulov, Toward a History of Byzantine Psalters..., p. 103, note 2.

64 "MS Gr 3. Psalter, XIV th c.", cf. Seymour de Ricci and W. J. Wilson, Census of medieval and renaissance manuscripts in the United States and Canada. Vol. I, New York, The H. W. Wilson Company, 1935, p. 971.

${ }^{65}$ Georgi R. Parpulov, Toward a History of Byzantine Psalters..., p. 103; see also p. 103, note 5.

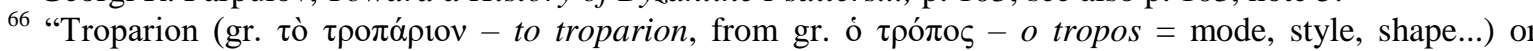
sticheron - is the oldest and most fundamental form of the liturgical hymnographic poetry. In the Greek language, the troparion respects, as form, the laws of poetic composition (rhythm, rhyme, number of syllables); by translating into Romanian, is rendered in prose, respecting the substance, to the detriment of the form...", Fr. Prof. PhD E. Branişte and Prof. Ecaterina Branişte, Dicţionar enciclopedic... (Encyclopaedic Dictionary...), pp. 522-523.

67 "Cambridge MA, Harvard University, Houghton Library, Greek MS 3”, cf. Georgi R. Parpulov, Toward a History of Byzantine Psalters..., p. 103.

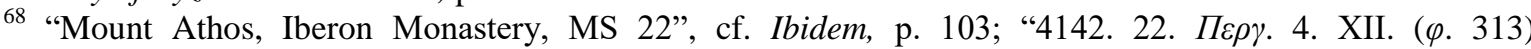

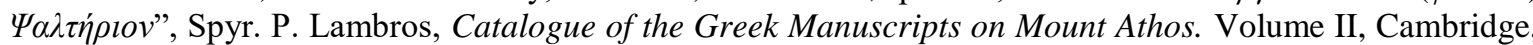
At the University Press, 1900, p. 3.

69 "Mount Athos, Pantokrator Monastery, MS 43", cf. Georgi R. Parpulov, Toward a History of Byzantine

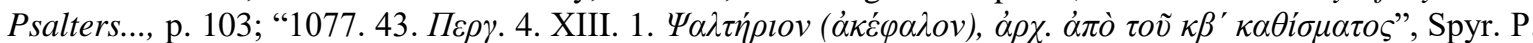
Lambros, Catalogue of the Greek Manuscripts on Mount Athos. Volume I, Cambridge, At the University Press, 1895, p. 97.

70 "These are the oldest known Psalters with short hymns (troparia) and prayers inserted at each Kathisma, i.e. after Psalms 8, 16, 23, etc. Harv. 3 is datable, through a paschal table it contains, to AD 1104; Iber. 22 and Pantokr. 43 are written in very similar hands and must have been copied around the same time", Georgi R. Parpulov, Toward a History of Byzantine Psalters..., p. 103.
} 


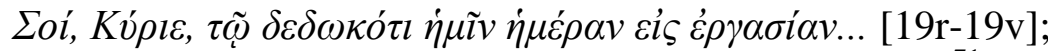

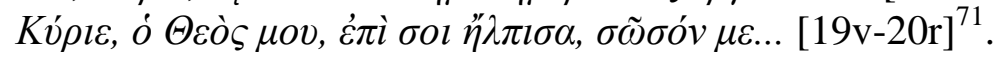

It should be noted, however, that G. Parpulov indicates another codex, "Mount Sinai,

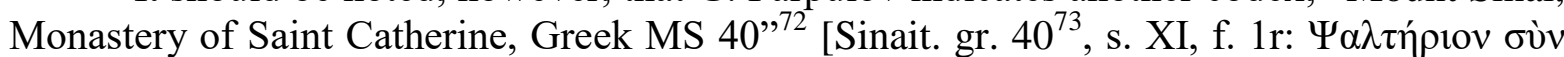

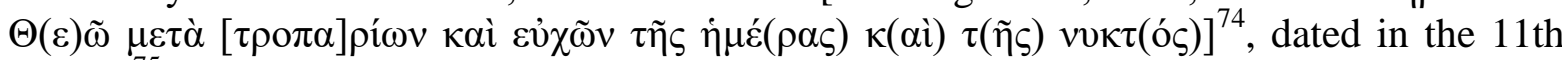
century $^{75}$, whose title refers directly to the so-called "prayers of the Kathismata", which confirms their existence already a century earlier.

\section{4. "PRAYERS OF THE ANTIPHONS"-}

\section{THE CONSTANTINOPOLITAN TRADITION}

"Complete" information on the so-called "prayers of the antiphons" (similar to the "prayers of the Kathismata" of the Palestinian tradition) we do not have unfortunately, although the existence of such prayers, their number (74), was signaled early (11th century), being mentioned for the first time in the colophon of the famous manuscript Coisl. 213 (a. 1027), which, according to the specialists, records Constantinopolitan liturgical practices ${ }^{76}$.

We will present in what follows the text of the colophon of this codex (Coisl. 213, a. 1027), manuscript presented at the Oriental Pontifical Institute in Rome (PIO), as "Eucologio della Grande Chiesa" (that is from Hagia Sophia) ${ }^{77}$, by J. Duncan ${ }^{78}$ and J. Maj ${ }^{79}$ :

"COI ${ }^{80}: 211$ (cf. J. Duncan:VII, J. Maj:147):

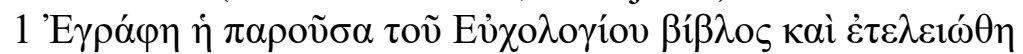

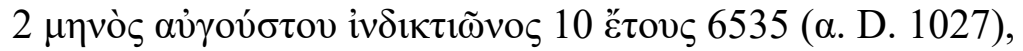

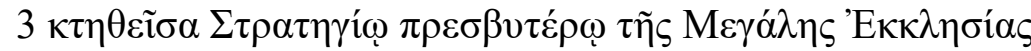

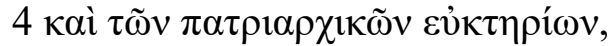

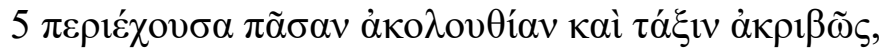

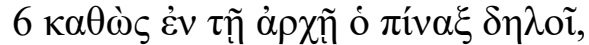

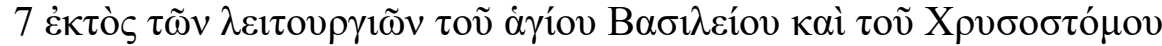

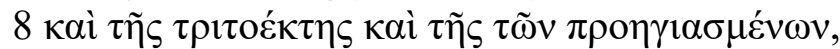

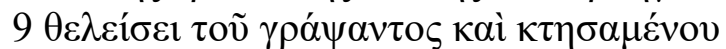

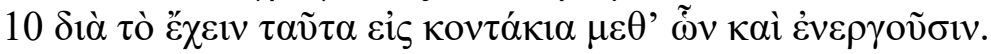

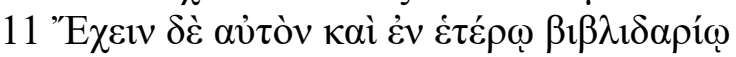

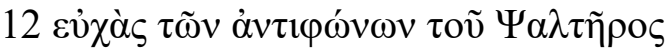

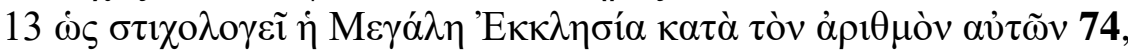

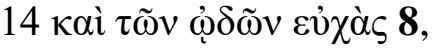

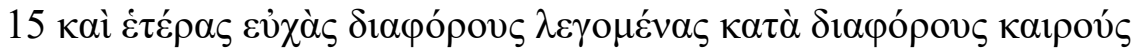

\footnotetext{
${ }^{71}$ See also the prayers in Georgi R. Parpulov, Toward a History of Byzantine Psalters..., pp. 190, 195, 199, 205, 207 and 210.

${ }^{72}$ Toward a History of Byzantine Psalters..., p. 103.

73 "Psalms, saec. XIV", V. Gardthausen, Catalogus codicum Graecorum Sinaiticorum, Oxonii, E Typographeo Clarendoniano, 1886, p. 11.

${ }_{74}^{74}$ Cf. Toward a History of Byzantine Psalters..., pp. 103 and 103, note 4.

${ }^{75}$ Unfortunately, G. Parpulov does not indicate the sources on which he relies when he dates this codex back to the $11^{\text {th }}$ century (cf. Toward a History of Byzantine Psalters..., p. 103, note 4).

${ }^{76}$ M. Arranz, L'Eucologio Costantinopolitano..., pp. 13-14.

${ }^{77}$ Ibidem, p. 14.

${ }^{78}$ Coislin 213. Euchologe de la Grande Église, Roma, Dissertatio ad Lauream Pontificio Istituto Orientale, 1983.

${ }^{79}$ Coislin 213. Eucologio della Grande Chiesa. Manoscritto della Biblioteca Nazionale di Parigi (ff. 101211), Roma, Tesi di Laurea Pontificio Istituto Orientale, 1990.

${ }^{80}$ This logo designates the fund "Coislin", to which belongs codex 213 (a. 1027).
} 


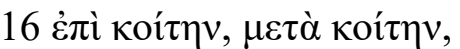

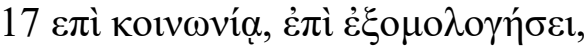

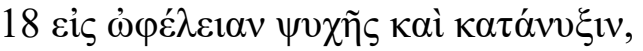

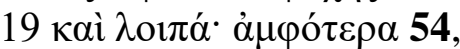

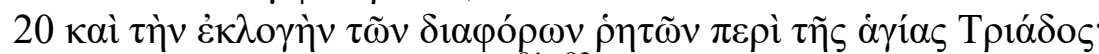

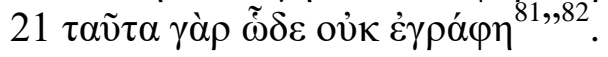

The "fundamental" problem raised by the Constantinopolitan (but also the Jerusalemtype) prayers is, according to Father M. Arranz, the type of these prayers, namely, their probable writing (construction) as a paraphrase, in the sense that some of the so-called "sacerdotal prayers" in the ordinance of Vespers and Matins, real reminiscences of the old "prayers of the antiphons", could be true paraphrases to "David's Psalms":

"La prière qui, à Jérusalem au $\mathrm{IV}^{\mathrm{e}}$ s., suivait chaque psaume tandis qu'à Constantinople, selon l'Euchologe ancien, elle le précédait, et qui était dite par le prêtre, était-elle une prière de médiation sacerdotale, ou était-ce plutôt une paraphrase destinée à introduire le psaume (à Constantinople) ou à le compléter (à Jérusalem) en lui donnant un sens chrétien? Etaient-ce des prières vraiment sacerdotales ou simplement explicatives?" 83 .

Note that prayers as paraphrases to Psalms are also found in codex Vat. gr. 783 $\left[\right.$ Hymnologia, graece ${ }^{84}, 14^{\text {th }}$ century ${ }^{85}$ ], but not only; but more on this topic we wrote in a small subchapter of the Doctoral Thesis ${ }^{86}$. follows:

Father M. Arranz describes the type of prayers in the manuscript Vat. gr. 783 as

"In genere si può affermare che queste preghiere non erano essenzialmente sacerdotali, ma riservate ad uso privato anche se probabilmente comunitario. In esse oltre che la lunghezza non abituale nelle preghiere pubbliche e ufficiali, si osserva l'uso della prima persona al singolare, fatto escluso delle preghiere sacerdotali, tutte alla prima persona del plurale"

Returning to the type of prayers called "Constantinopolitan", we would like to point out that the information provided by Saint Simeon of Thessalonica $(\dagger 1429)$ clearly shows us that certain "liturgical" prayers of his time represented a "paraphrase" of some of David's Psalms:

"...for the first of the Vespers' prayers encompasses the meaning of the psalm, with words taken from it: "Merciful and gracious God". The other prayers can be seen as having the same meaning with psalms, antiphons, and words from them (...), the prayer and the words of the Psalms are spoken. Their meaning is to bring all to God through the priest..." ${ }^{, 88,89}$.

\footnotetext{
${ }^{81}$ It is a drafting of the text called "diplomatic" by specialists.

${ }^{82}$ Cf. M. Arranz, L'Eucologio Costantinopolitano..., pp. 13-14.

83 "Le sacerdoce ministériel...", p. 193.

${ }^{84}$ T. De Marinis, La legatura artistica in Italia nei secoli XV e XVI. Notizie ed elenchi. Volume III, Firenze, Fratelli Alinari-Istituto di Edizioni Artistiche, 1960, p. 44, n 2776.

${ }^{85}$ As for the dating of the codex see N. Preda, Preghiere salmiche di autori vari secondo il codice "Vaticano Greco 783" (ff. 1-96r). Doctoral thesis, Bucharest, Granada Publishing, 2016, pp. 35-36.

86 "9. Le preghiere del codice Vat. gr. 783: preghiere sacerdotali come parafrasi di certi salmi oppure preghiere di uso monastico privato", N. Preda, Preghiere salmiche..., pp. 459-463.

${ }^{87}$ Judicium de Thesi Doctorali N. Preda, Roma, Pontificio Istituto Orientale, 2005, p. 4; see also N. Preda, Preghiere salmiche..., pp. 10-11.

${ }^{88}$ Sfântul Simeon Arhiepiscopul Tesalonicului, Tratat asupra tuturor dogmelor credinţei noastre ortodoxe, după principii puse de Domnul nostru Iisus Hristos şi urmaşii Săi (Saint Simeon Archbishop of Thessalonica,
} 
On the "type" of Constantinopolitan sacerdotal prayers ${ }^{90}$ we will write more widely elsewhere.

However, we would like to point out here yet another aspect related to these prayers, even if, in the opinion of the specialists, it seems to be a marginal (peripheral) issue ${ }^{91}$ namely, their meaning and origin:

"Arranz, nel suo articolo sopra citato ${ }^{92}$ si chiede qual'è l'origine ed il senso di queste preghiere, dette al plurale e quindi anche a nome dei fedeli..."

\section{THE SO-CALLED "PRAYERS OF THE KATHISMATA" - THE PALESTINIAN TRADITION}

The comments of Father Arranz on the Palestinian "prayers" (perhaps including the so-called "prayers of the Kathismata") seem to be very "clear":

"Nous ne connaissons pas les prières originales de l'office palestinien; personnellement nous pensons que, comme office monastique, il n'en avait pas. Lorsqu'on a voulu lui adapter les prières de l'Euchologe de Constantinople, il a fallu forcer les choses en essayant de mettre le nouvel office en accord avec les prières de l'ancien",94.

On the other hand, Father Boris Hološnjaj seems to "contradict" to some extent the hypothesis of Father M. Arranz when he remembers the so-called Palestinian ordinance, also called "kanon tês psalmodías"95 of Sabbait monks, which contained besides "psalmody", also "prayers" (very likely also the so-called "prayers of the Kathismata"); unfortunately, about the type of these prayers, which seem to be, without a doubt, of private use (ie, the personal order of the monks) ${ }^{96}$, he does not give us any other clue.

Moreover, referring in the same context to the liturgical tradition of Sinai and of Blessed Nilus, who "observed" the Palestinian ordinances, he states:

Treaty on all the Dogmas of our Orthodox Faith, according to the Principles of Our Lord Jesus Christ and His Followers). Volume II, in the Colection "From the Beauties of Christian Living" 2, Suceava, Publishing House of Suceava and Rădăuţi Archbishopric, 2003, p. 91; see also N. Preda, Preghiere salmiche..., p. 459.

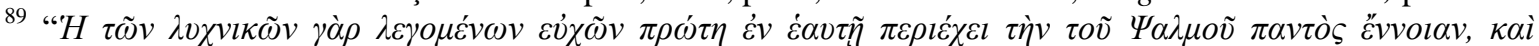

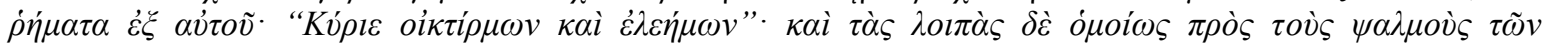

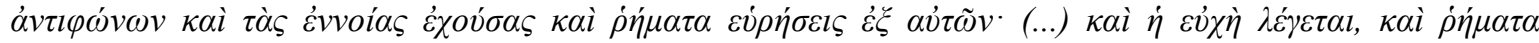

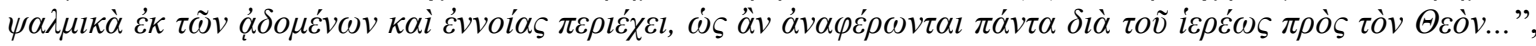
$P G 155$, p. 628B; "La première prière des lucernaires qui contient la signification du psaume (...) Les autres (prières) contiennent la signification des psaumes des antiphôna...", M. Arranz, "L'office de l'Asmatikos Hesperinos («vêpres chantées») de l'ancien Euchologe byzantin, II partie: La psalmodie”, in Orientalia Christiana Periodica 44 (1978), p. 411.

${ }^{90}$ See also Boris Hološnjaj, Tipikon della Chiesa bizantina - storia della sua formazione, Roma, Dispense Pontificio Istituto Orientale, 2004-2005, p. 7.

91 "Mais cette question de la place et de la destination des prières presbytérales des vêpres et des matines, tout en restant dans le thème de notre présent travail, est une question périphérique", M. Arranz, "Le sacerdoce ministériel...", p. 189.

92 “... quel sens et quel rôle peuvent avoir ces sept prières sacerdotales, rédigées au pluriel et donc au nom des fidèles, dites d'affilée et de plus en secret", M. Arranz, "Les prières sacerdotales des vêpres byzantines", p. 85 .

${ }^{93}$ M. Nin, Ufficiatura bizantina..., p. 47, note 217.

${ }^{94}$ M. Arranz, "Le sacerdoce ministériel...", p. 189.

95 "Questo secondo modo della preghiera dei monaci sabaiti è conosciuto sotto la denominazione "kanon tês psalmodías" e comprendeva i salmi e le preghiere. Sembra che il "kanon tês psalmodías" i monaci recitavano nelle loro lingue materne", Tipikon della Chiesa bizantina..., pp. 3-4.

${ }^{96}$ M. Arranz, "Le sacerdoce ministériel...", p. 192. 
"A questo punto seguiva la prima stasis di cinquanta salmi. Finiti questi Nilo recitava 50 volte Kyrie eleêson e Padre nostro dopodiché uno dei suoi discepoli leggeva la Lattera di Giacomo mentre gli altri ascoltavano seduti. Dopo la seconda stasis di cinquanta salmi e le preghiere come dopo la prima..." ${ }^{\prime 97}$.

This mention also means that the so-called "prayers" that followed the continuous reading of the Psalms (the 150, divided into three states) of the community ordinance, were in fact "Kyrie eleison, 50 times and Lord's Prayer","

So, according to Father Boris Hološnjaj, we distinguish two types of prayer in the Palestinian tradition (sabbait), depending, of course, on the two types of ordinances (private and common or communal):

a) "prayers" which follow the "psalmody" and which are of private use ${ }^{99}$, but on which we know nothing;

b) "prayers" that follow "the continuous reading" of the Psalter and which are part of the community ordinance (common) and which are "Kyrie eleison, 50 times and Lord's Prayer," 100

However, Father Arranz advances the assumption regarding the Palestinian "prayers", stating that:

"Nous pouvons donc avancer l'affirmation que l'office byzantin actuel, d'origine monastique palestinienne, ne prévoyait pas de prière psalmique; ni privée comme c'était le cas en Egypte ${ }^{101,102}$ et peut-être en Cappadoce ${ }^{103}$ et Antioche, ni officielle comme c'était le cas à Jérusalem ${ }^{104}$ au $\mathrm{IV}^{\mathrm{e}}$ siècle $^{105}$, ou à Constantinople ${ }^{106}$ tant que

\footnotetext{
${ }^{97}$ Boris Hološnjaj, Tipikon della Chiesa bizantina..., p. 4.

98 "L'office monacal dure toute la nuit et se fait dans un cadre fort proche de l'office byzantin actuel; il comprend la récitation de tout le psautier et la lecture de trois épîtres catholiques et n'a comme prière que le Notre Père répété à différents moments de l'office et de longues séries de Kyrie eleison. Aucune autre prière", M. Arranz, "Le sacerdoce ministériel...", p. 192.

${ }^{99}$ See also M. Arranz, "Le sacerdoce ministériel...", p. 192.

100 "The Apostles (...) asked the Savior to teach them how to pray (Matthew 6) and, since then, the prayer of the Savior has not ceased to remain the most important prayer of the Church", Hierom. PhD Petru Pruteanu, "Evoluţia Rânduielilor tipiconale..." (The Evolution of the Typikon...), p. 63.

101 “...Uno si alzava in mezzo e cantava i salmi al Signore. Intanto tutti stavano seduti (come è ancora uso in Egitto), con la mente intensamente fissa alle parole del cantore, e quando aveva cantato undici salmi, separati dalle preghiere inserite tra di loro...", Robert F. Taft, La liturgia delle ore in oriente e occidente. Le origini dell'ufficio divino e il suo significato per oggi, Roma, Edizioni Lipa, 2001, pp. 85-86; this is a passage from the work Despre aşezămintele cenobiţilor (About the Cenobitical Establishments) of Saint John Cassian ( $\dagger$ 435).

102 "In the monastic environment, starting with the 4th-5th centuries, some psalmodic ordinances developed, which, besides private prayers that did not have a fixed order, generated the evening-night and morning-day vigils. The basics of such a vigil were as follows: a) the protopsaltes read/ spoke 12 Psalms, after the last saying Alleluia; b) after each Psalm there was prayer in secret; c) at the abbot's sign there were made bows (together); d) the abbot was praying loudly...”, Hierom. PhD Petru Pruteanu, "Evoluţia Rânduielilor tipiconale..." (The Evolution of the Typikon...), p. 66.

103 "E cosí dopo aver trascorso la notte in una serie di salmodie interrotte da preghiere...", Robert F. Taft, $L a$ liturgia delle ore..., p. 63 (see also the chart on page 64); it's a text from a Scrisoare (Letter) (207:3) which St. Basil the Great $(\uparrow 379)$ sends to the clergy of New Caesarea (Cappadocia).

104 “A partire da quest'ora fino all'alba si recitano inni, si risponde ai salmi cosí come alle antifone: a ogni inno si fa una preghiera. Infatti due o tre sacerdoti e cosí alcuni diaconi ogni giorno si avvicendano con i monazontes per dire le preghiere a ogni inno e a ogni antifona", Robert F. Taft, La liturgia delle ore..., p. 74; it's a text from Descrierea Egeriei (Description of Egeria) (chap. 24).

105 "Another important testimony worth mentioning about the liturgical ordinances of the fourth century in the cathedral environment is Descrierea pelerinei Silvia Egeria (Description of the Pilgrim Silvia Egeria) (Peregrinatio ad Loca Sancta, year 384) which presents the daily routine of the ministry in the Church of the
} 
l'office asmaticos $^{107}$ y a été en vigueur ${ }^{108}$. Répétons que au moyen âge on a tenté, plusieurs solutions pour incorporer à l'office monastique les prières de l'Euchologe constantinopolitain. Une des solutions possibles est celle pratiquée aujourd'hui: l'office est célébré sans prières, mais celles-ci sont dites tout de même, en bloc et à voix basse. Il est vrai que le fait de dire les prières à voix basse est un phénomène très ancien et assez généralisé. Comment juger le fait que les moines palestiniens qui avaient élaboré un office d'une grande perfection technique et d'une surprenante richesse hymnologique, n'aient jamais songé à créer eux-mêmes ou à emprunter à d'autres traditions des prières pour les psaumes? Faut-il voir en cela une conséquence du simple fait qu'il n'y avait pas de prêtres parmi les moines, car, selon l'abbé Nil, c'étaient là deux «vocations» différentes et même contradictoires"109.

Another "liturgical province" that could be added to those mentioned by Father M.

Arranz is the island of Cyprus:

"Anche Epifanio (ca. 315-403), monaco in Giudea per trent'anni prima di diventare nel 367 vescovo di Salamina, al cap. 23 del suo trattato Sulla fede, scritto circa nel 374-377, parla di «inni e preghiere mattutini» e di «salmi e preghiere vespertini» (lychnikos). Da notare che egli parla di inni e preghiere mattutini e salmi e preghiere vespertini, cioè al plurale" 110 .

Finally, we want to point out that "deleted" recordings of the existence of the socalled "Palestinian" prayers are found, on the one hand, in manuscripts written later (Byzantine Liturgical Psalters), which contain such prayers (see for example ms. Ateniense $2478,14^{\text {th }}$ century and others ${ }^{111}$ ), as well as in the printed Liturgical Psalters (which we will recall in another subchapter). Codex Ateniense 2478 , which we have personally dealt with ${ }^{112}$, contains besides the Psalms, also prayers (65), which we have called, in general terms, "prayers of the Kathismata", some of which being unknown and unpublished.

Resurrection in Jerusalem. In ordinary days, there were 5 moments of prayer that consisted of the following elements: 1) monastic vigil at the singing of cocks made up of psalms and the prayers of priests and deacons; 2 ) in the morning - the psalms singed by the protopsaltes, and the prayer of the bishop with the bending of the heads; 3) Hour VI: the psalms singed by the protopsaltes, and the prayer of the bishop with the bending of the heads...", Hierom. PhD Petru Pruteanu, "Evoluţia Rânduielilor tipiconale..." (The Evolution of the Typikon...), p. 67.

106 “A partire del X secolo abbiamo già le prime testimonianze sulle preghiere presbiterali provenienti dalla tradizione dell'Asmatikê Akolouthia inserite nell'ufficio delle Ore (Vespro e Mattutino) della tradizione monastica palestinese. Si tratta delle prime sette preghiere del Vespro dell'Asmatikê Akolouthia e delle dodici preghiere del Mattutino nei corrispondenti uffici monastici”, Boris Hološnjaj, Tipikon della Chiesa bizantina..., p. 13.

107 "2) Le cinque preghiere fra i quali le prime tre corrispondevano ai salmi delle tre antifone mentre le ultime due erano le preghiere dell'inclinazione del capo (euchê thês kefaloklisias) e di congedo (euchê thês apolyseos)...", Boris Hološnjaj, Tipikon della Chiesa bizantina..., p. 8.

108 "This is where the service asmatikon akolouthia - "the ordinance of singing" develops, which implied antiphonal singing. Actually, asmatikon akolouthia was not a service in the direct sense of the word, but a kind of job model, a schema for Vespers and Matins. It implied: a) three prayers of the priest with litanies; b) three antiphons (in fact Psalms antiphonically sung), one after each prayer; c) the Dismissal prayer with a litany for demands; and d) the final prayer with bending of the heads", Hierom. PhD Petru Pruteanu, "Evoluţia Rânduielilor tipiconale..." (The Evolution of the Typikon...), p. 87.

${ }^{109}$ M. Arranz, "Le sacerdoce ministériel...", p. 192.

${ }^{110}$ Robert F. Taft, La liturgia delle ore..., p. 65.

111 According to an "Appendix" ("Appendix D5: Prayers Found in Psalters and Horologia") from the study of G. Parpulov, there would be no less than 30 pages of incipient, about 412 prayers, recorded in manuscripts (Psalters), with those mentioned, it is true, also in the Horologion of the so-called "prayers of the Kathismata”, cf. Toward a History of Byzantine Psalters..., pp. 182-211.

${ }^{112}$ N. Preda, Aşa-numitele "rugăciuni ale catismelor"... (The so-called "Prayers of the Kathismata”...). 


\section{6. "SACERDOTAL" PRAYERS - OTHER CHARACTERISTICS}

There are some unclear explanations regarding the so-called sacerdotal prayers and we think it is welcome to present them in this context.

A general exposition of the prayers known as "sacerdotal" is found at Father M. Arranz:

"En regardant notre tableau ${ }^{113}$ nous voyons que les prières avaient trois fonctions différentes: les unes, les plus nombreuses, précédaient les psaumes (soit groupés en antiphones, soit isolés); d'autres accompagnaient la synaptie de demandes à la fin des offices: la prière [7] aux vêpres et la prière [12] aux matines; de ces prières accompagnant les synapties nous avons déjà un précédent dans les vêpres et matines du VIII ${ }^{\mathrm{e}}$ livre des Constitutions Apostoliques; une troisième catégorie comprenait les prières d'inclination de la tête ou de bénédiction: celles-ci aussi nous les trouvons déjà dans les mêmes Constitutions"114.

Here are some of the peculiarities of these prayers:

"Les prières $[\mathbf{I}]$ à $[\mathbf{8}]^{115}$ seront séparées en deux groupes de nombre variable. Celles du premier groupe, les premières, accompagneront la psalmodie des kathismata (d'un à trois, selon les traditions et selon les époques de l'année): en raison d'une prière par kathisma en règle générale, ou trois si on sépare les trois doxai de chaque kathisma. Les dernières prières du groupe [I]-[8] c.à.d., celles qui ne trouveront pas de place dans la psalmodie, seront dites entre les odes du kanôn: après la $3^{\mathrm{e}}$ et la $6^{\mathrm{e}}$. Quelque prière pourra même disparaître" $" 116$.

What is special is, in our opinion, the mention of the existence in ancient times of socalled "sacerdotal prayers" spoken after each Song of Canons ${ }^{117}$ from the Holy Thursday (on the Holy Week only on Thursday and on Saturday we have the whole Canon) ${ }^{118}$ and beginning with Easter Sunday, given that during this period we do not have kathismata of the Psalter at Matins; this particularity is also signaled by Father M. Arranz:

"A l'orthros du Jeudi Saint et du Dimanche de Pâques, où il n'y a pas de psalmodie, le Typicon d' Ibîrôn (KEKELIDZE, 283, 292) prévoit une prière et sa correspondante synaptie après chaque ode du kanôn. Dans la praxis actuelle, seules les synaptai suivent les odes aux matines de Pâques. A Messine, chaque ode était suivie de synaptie et de lecture patristique ce même jour. Nous avons déjà vu que le lendemain des fêtes du Seigneur, les odes I à 6 remplaçaient la psalmodie du psautier (cf. p. 70, note I); même praxis à Ibîrôn (cf. KEKELIDZE, 247)"119.

\footnotetext{
${ }^{113}$ Cf. M. Arranz, "Le sacerdoce ministériel...”, pp. 188-189.

114 "Le sacerdoce ministériel...", p. 190.

115 These are the first eight prayers of those called "of the Matins".

${ }_{116}$ M. Arranz, "Les prières presbytérales des matines...", pp. 86-87.

117 "The canon is the most developed of Christian religious poetry as it brings together in a new unit hymns (odes) formed, as we have seen, each of three or more stanzas or stichera...”, Fr. Prof. PhD E. Branişte and Prof. Ecaterina Branişte, Dicţionar enciclopedic... (Encyclopaedic Dictionary...), p. 85.

${ }_{118}$ Triodion which includes church services from the Sunday of the Publican and Pharisee until the Holy Saturday, Bucharest, Publishing House of the Bible and Mission Institute of the Romanian Orthodox Church, 2010, pp. 584-590, 665-670.

119 "Les prières presbytérales des matines...", p. 87, note 2.
} 


\section{THE TYPE OF SO-CALLED "PSALMIAN PRAYERS": "SACERDOTAL MEDITATIONS" OR "SIMPLE PARAPHRASE"?}

In an article from the ' $70 \mathrm{~s}^{120}$, Father Arranz wondered how the so-called "psalmian prayers" could be understood: "sacerdotal meditations" or "simple paraphrase"?

To this question, we will try to answer further, specifying only a few of the characteristics of the "psalmian prayers", because, as we shall see, an exact determination of them is still difficult to achieve.

Thus, we will first record some essential passages from the study of Father M. Arranz, where he tries to "solve" as much as possible this dilemma:

"La prière qui, à Jérusalem au $\mathrm{IV}^{\mathrm{e}} \mathrm{s}$., suivait chaque psaume tandis qu'à Constantinople, selon l'Euchologe ancien, elle le précédait, et qui était dite par le prêtre, était-elle une prière de médiation sacerdotale, ou était-ce plutôt une paraphrase destinée à introduire le psaume (à Constantinople) ou à le compléter (à Jérusalem) en lui donnant un sens chrétien? Etaient-ce des prières vraiment sacerdotales ou simplement explicatives? Dans le premier cas les moines, en constituant des communautés sans prêtres, ne pouvaient pas adopter des prières vraiment sacerdotales. Dans le second cas, vivant une haute vie spirituelle, ils ne sentaient pas le besoin d'interpréter les psaumes, qui étaient eux-mêmes leur prière essentielle. Les Alleluia, Gloria Patri, Pater noster et Kyrie eleison, qui parsemaient la récitation du psautier, leur suffisaient. Ils avaient d'ailleurs conservé les prostrations entre les psaumes $^{121}$. (...) Pour ce qui est des prières de l'Euchologe qui accompagnent les psaumes et qui sont sept sur neuf à vêpres et onze sur treize à matines (voir tableau) ${ }^{122}$, nous pouvons donc avancer une première conclusion: deux prières psalmiques à vêpres ([1] et [8]) et deux à matines ([10] et [11]) sont vraiment psalmiques; les autres cinq à vêpres, et neuf à matines, accompagnent les psaumes sans s'y référer, même d'une façon générale, vu que les citations de l'Ecriture et spécialement du Psautier, sont assez rares et imprécises. D'où viennent ces prières? Ont-elles étaient créées pour accompagner les antiphones ou existaient-elles déjà avant d'être réunies dans l'Euchologe? Une réponse précise évidemment n'est pas possible; nous allons essayer un peu plus loin de présenter une hypothèse, après avoir considéré les prières des synapties" $" 123$.

Note that important insights on the type of the so-called "sacerdotal prayers" are also found in Father M. Nin:

"Preghiera I. Si tratta di una serie di parafrasi del salmo 85 che nel vespro di Costantinopoli si trovava pure all'inizio di quest'ora; attualmente non ha allusione alcuna a qualche ufficiatura. Si tratta di un buon esempio di preghiera salmica, in cui il singolare del salmo passa al plurale del testo. Forse la presente preghiera apparteneva a un insieme di preghiere salmiche

\footnotetext{
120 "Le sacerdoce ministériel...".

${ }^{121}$ Robert F. Taft, La liturgia delle ore..., pp. 218, 227, etc.

${ }^{122}$ Cf. M. Arranz, "Le sacerdoce ministériel...", pp. 188-189.

${ }^{123}$ M. Arranz, "Le sacerdoce ministériel...", pp. 193-194.
} 
che la Chiesa costantinopolitana ${ }^{124}$ aveva e che è andata persa, cf., ARRANZ, M., Les prières sacerdotales, pp. 88-89"125;

"Preghiera II-III. Due preghiere tipicamente vespertine, fatta da un'insieme di citazioni salmiche. Hanno una tematica simile, con una prima parte penitenziale: Signore nel tuo sdegno non ci accusare, e nella tua ira non ci castigare, ma agisci con noi secondo la tua clemenza... (preghiera II); Signore Dio nostro, ricòrdati di noi pecatori e inutili servi (preghiera III). Non sembra ispirata ad un unico salmo, ma a diversi testi. Si può trattare di una preghiera che accompagnava una litania di preghiere; infatti le espressioni e concedi che quanto resta del giorno presente sia pieno di pace e senza peccato, come pure tutto il tempo della nostra vita (preghiera II), ...tutto ciò che chiediamo di utile per la nostra salvezza (preghiera III), si trova nella litania dell'angelo di pace dopo il grande ingresso del vespro" ${ }^{26}$.

We would like to state in the conclusion of this subchapter that at the time when we were preparing the Doctoral Thesis [Preghiere salmiche di autori vari secondo il codice "Vaticano Greco 783" (ff. 1-96r)], we were not aware of the content of this article; we say this because, in a way, the prayers we have mentioned in this paper could be a "response" to the dilemma of the type of so-called "psalmian prayers".

We'll just give some of the coordinates of the type of prayers written in codex Vat. $g r .783$, characteristics on which the type of these prayers could easily be determined.

A first clue is the titles of the two collections of prayers:

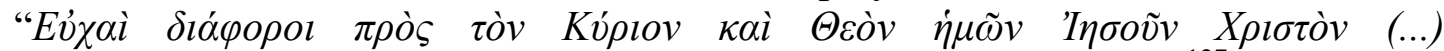

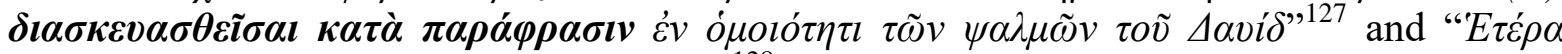

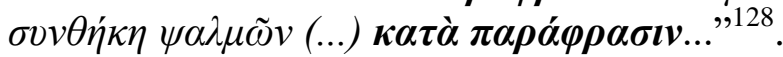

A second clue is also the titles of some of the prayers themselves:

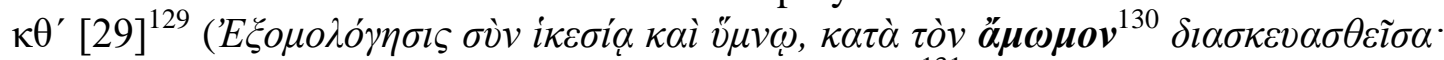

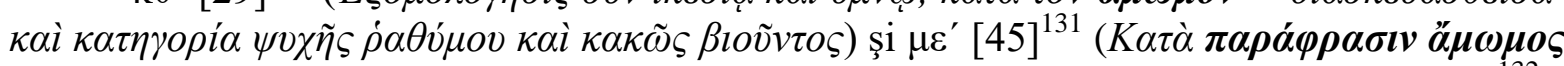

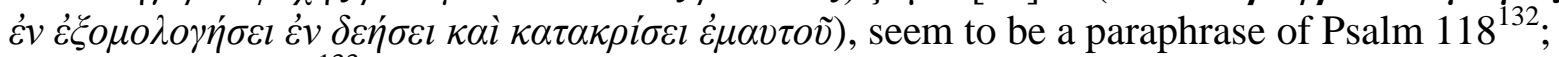

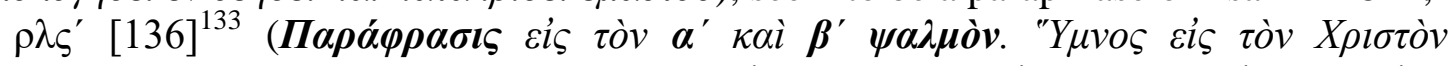

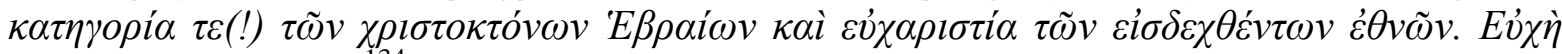

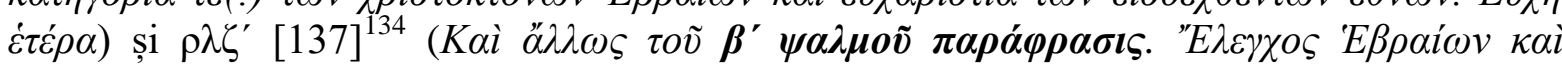
$\theta \varepsilon o \lambda o \gamma i \alpha$ vi $\pi \dot{\varepsilon} \rho \tau \tilde{\eta} \varsigma \sigma \omega \tau \eta \rho i \alpha \varsigma \tau \tilde{\omega} v \pi l \sigma \tau \tilde{\omega} v)$, seem to be a paraphrase of Psalms 1 and 2.

\footnotetext{
${ }^{124}$ See also Boris Hološnjaj, Tipikon della Chiesa bizantina..., p. 8.

${ }^{125}$ Ufficiatura bizantina..., p. 46, note 209.

${ }^{126}$ Ufficiatura bizantina..., p. 46, note 211 .

${ }^{127}$ Vat. gr. 783, 2v.

${ }^{128}$ Vat. gr. 783, 97r.

${ }^{129}$ Vat. gr. $783,49 \mathrm{v}-65 \mathrm{v}$.

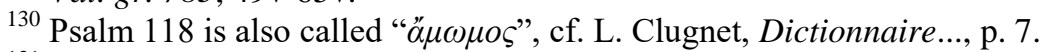

${ }^{131}$ Vat. gr. 783, 173r-182r.

132 Note that the "arbitrary" division of the prayers $\left[\kappa \theta^{\prime}(49 \mathrm{v}-65 \mathrm{v})\right.$ and $\left.\mu \varepsilon^{\prime}(173 \mathrm{r}-182 \mathrm{r})\right]$ from codex Vat. $g r$. 783 in "states" ["Les prières trop longues pour être dites sans interruption ont été divisées de différentes

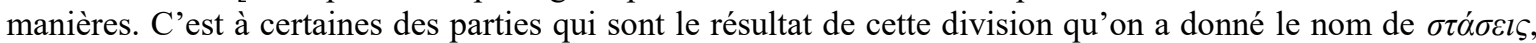
nom qui indiquait à l'origine qu'on devait les réciter ou les chanter debout", L. Clugnet, Dictionnaire..., p. 139], fortunately coincides with the natural division of Psalm 118 into three "states" [see Vat. gr. 783, 56v, 62r, 173r, 177r, 179v)].

${ }^{133}$ Vat. gr. 783, 242r-243v.

${ }^{134}$ Vat. gr. 783, 243v-245v.
} 
Even if we do not have a clear answer to the "type" of the so-called "psalmian prayers", we can still state, with the limits of rigor and in accordance with what we have mentioned above, that much of the prayers in the cult were written in the form of a paraphrase to certain Psalms.

\section{BYZANTINE LITURGICAL PSALTER - PECULIARITIES OF THE PRINTED EDITIONS}

Particular attention is paid by C. Korolevskij to the printed Psalters (he mentions, among other things, Vienna edition from 1793, which he found in Rome), which record a practice that he says is not reproduced in all the printed editions of the Psalter in Greek:

"Cette manière de lire le Psautier pourrait être très antique, parce que le Psautier était le seul livre de prières des anciens anachorètes: probablement en trouverait-on des vestiges dans les manuscrits. En tous cas, je ne l'ai jamais vu reproduit dans les éditions grecques, sinon dans celle de Vienne 1793, dont se trouve un exemlpaire à l'Institut Pontifical Oriental",135.

The hypothesis of C. Korolevskij is and is not a fair one, because there are others Psalters in Greek, which render together with "prayers of the Kathismata"136, the so-called "Titles of the Psalms" "137, both those attributed to Eusebius of Caesarea ${ }^{138,139}$ († 339), as well as others ${ }^{140}$; but about these particularities we will speak in what follows.

On the other hand, it is necessary to strengthen the supposition of $\mathrm{C}$. Korolevskij regarding the existence in the manuscript of the so-called "prayers of the Kathismata", because much of this topic has been dealt with lately; personally we have already written two studies on this subject, works already quoted [The so-called "Prayers of the Kathismata" according to Codex Ateniense 2478: (Liturgics Study) and Preghiere salmiche di autori vari secondo il codice "Vaticano Greco 783" (ff. 1-96r)].

C. Korolevskij adds, among other things, that "prayers of the Kathismata" is in all the editions of the Psalter in Slavonic, being originally important elements of an anachoretic ordinance:

"Il existe même un office à l'usage des ermites, ne comportant que le Psautier. Il se trouve dans toutes les éditions du Psautier slave. Avant chaque cathisme, après les prières habituelles du début de tout office, viennent trois tropaires, quarante Gòspodi pomilui, une prière à la Sainte Trinité, et on lit le cathisme. A la fin, quelques tropaires, quarante Gòspodi pomilui et une prière" ${ }^{\prime 14}$.

\footnotetext{
135 "La Codification de l'Office byzantin. Les essais dans le passé”, in Orientalia Christiana Periodica 19 (1953), p. 58

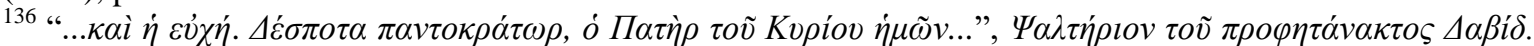

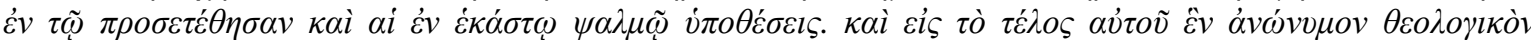

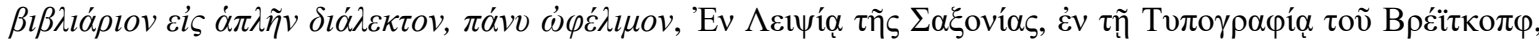
1781, p. 45.

${ }^{137}$ On the so-called "Titluri ale Psalmilor" (Titles of the Psalms) see also N. Preda, Preghiere salmiche..., pp. 472-487.

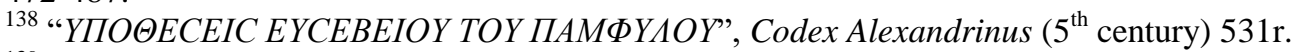

${ }^{139}$ Codex Alexandrinus (sec. V) 531v-532v, cf. Facsimile of the Codex Alexandrinus. Old Testament, Vol. III. [Psalm. Ecclesiast], Inghilterra, London (S. d.) and The Codex Alexandrinus (Royal MS. 1 D. V-VIII), in reduced photographic facsimile. Old Testament, part IV. I Esdras-Ecclesiasticus, London, 1957.

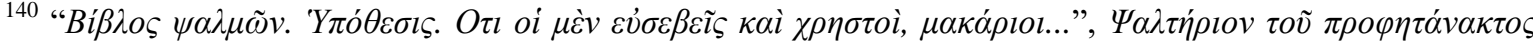
$\triangle \alpha \beta i \delta \ldots, 1$.

141 "La Codification de l'Office byzantin...", p. 58.
} 
To us, unfortunately, there is no study to cover this issue, but from what we have researched, the great majority of the Psalters in Romanian also have these prayers to us, probably because they have been translated from the Slavonic language.

Here are two of the old editions of the Psalter in Greek, printed in our country, containing both the "prayers of the Kathismata"142, and also "Titles of the Psalms":

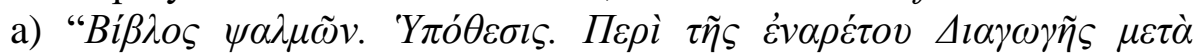

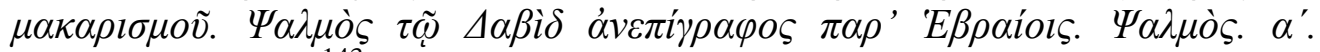

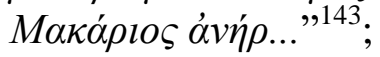

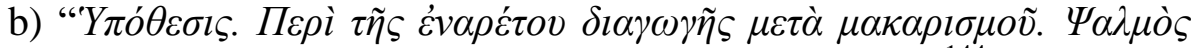

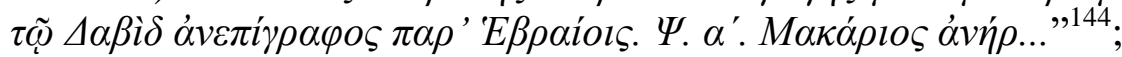

We must also add that according to the study of P. Salmon, Les "Tituli Psalmorum" des manuscrits latins (Études Liturgiques 3, Paris, Cerf, 1959), only six series had been discovered until that time ${ }^{145}$ ale "Titles of the Psalms"146, being attributed to several authors and belonging to different epochs. The earliest of these (written in Greek) is the fourth series (dated to the $4^{\text {th }}$ century) ${ }^{147}$, and is attributed to Eusebius of Caesarea.

\section{CONCLUSION}

Coming to the end, we can say that only a detailed study of these "prayers of the Kathismata" could confirm many of the "dilemmas" that these liturgical structures (prayers) still raise, such as the type, origin, author, and the age in which they were written, etc.

About the habit of reading the so-called "prayers of the Kathismata", as Ciril Korolevskij says, we know that it seems to be a very old and monastic custom in our Church, which was first encountered in the anchoret. Called prayers "of the Kathismata" (or "prayers of antiphons", as in the Constantinopolitan tradition), because they were usually placed after each of the 20 kathisma of the Psalter (or after the constantinopolitan "antiphons"), these prayers had different structures according to the two deterministic liturgical traditions, the Jerusalem and Constantinopolitan ones.

As far as current practice is concerned (also seen as a true continuation of ancient anachoretic-type usage), we would like to recall a former "custom" of some monasteries in Moldova (for example Sihastria Monastery) ${ }^{148}$, which made the order of reading the Psalter and the so-called "prayers of the Kathismata" truly a daily liturgical rule, a real "continual prayer".

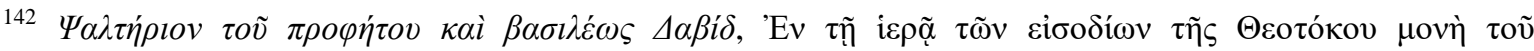

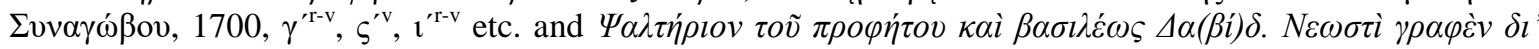

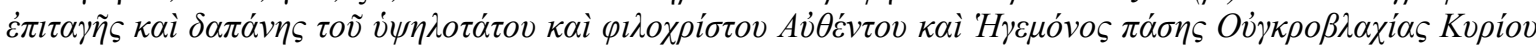

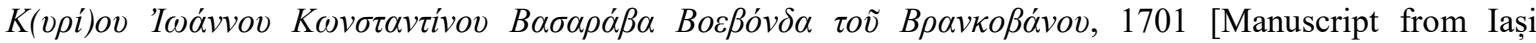
Metropolitan Library, Fond HH Teoctist, No. 12] 9r-9v, 17r etc.

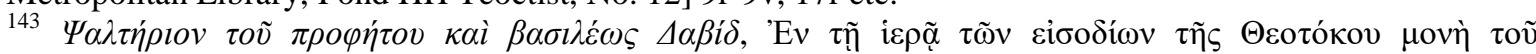
$\Sigma v v \alpha \gamma \omega \dot{\beta} \mathrm{ov}, 1700, \alpha^{\prime}$.

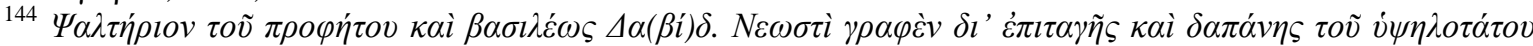

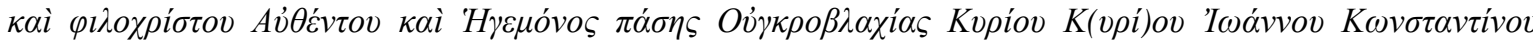

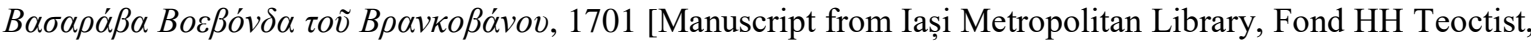
No. 12] 3r.

145 "Les six séries de titres publiées dans ce volume sont les seules qui existent encore, à notre connaissance", Les “Tituli Psalmorum”..., p. 30.

146 “... la série I est la plus répandue, tandis que les III, IV et VI y sont assez rares; la $\mathrm{V}^{\mathrm{e}}$ est tout à fait inconnue", Ibidem, p. 34.

147 "En tout cas, dès le IV ${ }^{\mathrm{e}}$ siècle, existent certainement celle d' Eusèbe (IV)...", Ibidem, p. 28.

148 See also Hieromonk Makarios of Simonopetra, Triodul explicat. Mistagogia timpului liturgic (Lenten Triodion Explained. The Mistagogy of the Liturgical Time). Translation: deac. Ioan I. Ică jr, Sibiu, Deisis Publishing, $2003^{2}$, p. 151.
} 


\section{BIBLIOGRAPHY:}

[1] Arranz, M., Judicium de Thesi Doctorali N. Preda, Roma, Pontificio Istituto Orientale, 2005

[2] Arranz, M., "Le sacerdoce ministériel dans les prières secrètes des Vêpres et des Matines byzantines", în Euntes docete XXIV (1971), pp. 186-219

[3] Arranz, M., "Les grandes étapes de la Liturgie Byzantine: Palestine-Byzance-Russie: Essai d'aperçu historique", in Liturgie de l'église particulière et liturgie de l'église universelle, Bibliotheca Ephemerides Liturgicae Subsidia 7, Roma, Centro Liturgico Vincenziano-Ed. liturgiche, 1976, pp. 43-72

[4] Arranz, M., "Les prières presbytérales des matines byzantines $-2^{\text {de }}$ partie: Les manuscrits", in Orientalia Christiana Periodica 38 (1972), pp. 64-115

[5] Arranz, M., "Les prières sacerdotales des vêpres byzantines", in Orientalia Christiana Periodica 37 (1971), pp. 85-124

[6] Arranz, M., L'Eucologio Costantinopolitano agli inizi del secolo XI. Hagiasmatarion \& Archieraticon (Rituale \& Pontificale) con l'aggiunta del Leiturgikon (Messale), Roma, Editrice Pontificia Università Gregoriana, 1996

[7] Arranz, M., "L'office de l'Asmatikos Hesperinos («vêpres chantées») de l'ancien Euchologe byzantin, II ${ }^{\mathrm{e}}$ partie: La psalmodie", in Orientalia Christiana Periodica 44 (1978), pp. 391-412

[8] Arranz, M., "L'office de l'Asmatikos Orthros («matines chantées») de l'ancien Euchologe byzantin", in Orientalia Christiana Periodica 47 (1981), pp. 122-157

[9] Borgia, N., Horologion. Diurno delle chiese di rito bizantino, in Orientalia Christiana $56=$ 16/I, Roma, Pontificio Istituto Orientale, 1929, pp. 152-254

[10] Braniş̧e, E., Fr. Prof. PhD and Prof. Ecaterina Branişte, Dicţionar enciclopedic de cunoştințe religioase (Encyclopaedic Dictionary of Religious Terms), Caransebeş, Diocesan Publishing, 2001

[11] Branişte, E., Fr. Prof. PhD Liturgica Specială pentru institutele teologice (Special Liturgy for Theological Institutes), Bucharest, Publishing House of the Bible and Mission Institute of the Romanian Orthodox Church, $1985^{2}$

[12] Ceaslov (Horologion), Bucharest, Publishing House of the Bible and Mission Institute of the Romanian Orthodox Church, 2001

[13] Clugnet, L., Dictionnaire grec-français des noms liturgiques en usage dans l'Église grecque, Paris, A. Picard et fils, 1895

[14] De Marinis, T., La legatura artistica in Italia nei secoli XV e XVI. Notizie ed elenchi. Volume III, Firenze, Fratelli Alinari-Istituto di Edizioni Artistiche, 1960

[15] de Ricci, Seymour and W. J. Wilson, Census of medieval and renaissance manuscripts in the United States and Canada. Vol. I, New York, The H. W. Wilson Company, 1935

[16] Devreesse, R., Codices Vaticani Graeci (604-866), t. III, Roma, In Bibliotheca Vaticana, 1950

[17] Duncan, J., Coislin 213. Euchologe de la Grande Église, Roma, Dissertatio ad Lauream Pontificio Istituto Orientale, 1983

[18] Facsimile of the Codex Alexandrinus. Old Testament, Vol. III. [Psalm. Ecclesiast], Inghilterra, London (S. d.)

[19] Gardthausen, V., Catalogus codicum Graecorum Sinaiticorum, Oxonii, E Typographeo Clarendoniano, 1886

[20] Hieromonk Makarios of Simonopetra, Triodul explicat. Mistagogia timpului liturgic (Lenten Triodion Explained. The Mistagogy of the Liturgical Time). Translation: deac. Ioan I. Ică jr, Sibiu, Deisis Publishing, $2003^{2}$

[21] Hološnjaj, Boris, Tipikon della Chiesa bizantina - storia della sua formazione, Roma, Dispense Pontificio Istituto Orientale, 2004-2005

[22] Hunger, Herbert, Otto Kresten und Christian Hannick, Katalog der griechischen Handschriften der Österreichischen Nationalbibliothek, Teil 3/2. Codices Theologici 101-200 [Museion. Veröffentlichungen der Österreichischen Nationalbibliothek. Neue Folge herausgegeben von der Generaldirektion. Vierte Reihe: Veröffentlichungen der Handschriftensammlung. Erster Band, Teil 3/2], Wien, Hollinek, 1984 


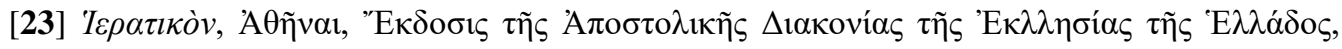
2000

[24] Il Signore della gloria. Preghiere della "Grande Chiesa" bizantina. Traduzione e note di Stefano L. Parenti, Milano, Edizioni Paoline, 1988

[25] Korolevskij, C., "La Codification de l'Office byzantin. Les essais dans le passé", in Orientalia Christiana Periodica 19 (1953), pp. 25-58

[26] Lambros, Spyr. P., Catalogue of the Greek Manuscripts on Mount Athos. Volume I, Cambridge, At the University Press, 1895

[27] Lambros, Spyr. P., Catalogue of the Greek Manuscripts on Mount Athos. Volume II, Cambridge, At the University Press, 1900

[28] Liturghier (Hieratikon), Bucharest, Publishing House of the Bible and Mission Institute of the Romanian Orthodox Church, 2000

[29] Liturghier cuprinzând Vecernia, Utrenia, Dumnezeieștile Litughii ale Sfinților: Ioan Gură de Aur, Vasile cel Mare, Grigorie Dialogul (a Darurilor mai înainte Sfințite), Rânduiala Sfintei Impărtășiri și alte rugăciuni de trebuință (Hieratikon including Vespers, Matins, Divine Liturgies of Saints: John Chrysostom, Basil the Great, Gregory the Dialogue (of the Presanctified Gifts), the Order of Holy Communion and other necessary prayers), Bucharest, Publishing House of the Bible and Mission Institute of the Romanian Orthodox Church, 2012

[30] Maj, J., Coislin 213. Eucologio della Grande Chiesa. Manoscritto della Biblioteca Nazionale di Parigi (ff. 101-211), Roma, Tesi di Laurea Pontificio Istituto Orientale, 1990

[31] Mateos, J., Celebrarea cuvântului în Liturghia bizantină. Studiu istoric (Celebrating the Word in Byzantine Liturgy. Historical Study). Translation and notes by Cezar Login, ClujNapoca, Renașterea Publishing, 2007

[32] Mateos, J., "Office de minuit et office du matin chez S. Athanase", in Orientalia Christiana Periodica 28 (1962), pp. 173-180

[33] Molitfelnic cuprinzând Slujbe, Rânduieli şi Rugăciuni săvârşite de preot la diferite trebuinţe din viaţa creştinilor (Euchologion including Services, Ordinances and Prayer spoken by the Priests on Various Necessities from the Life of Christians), Bucharest, Publishing House of the Bible and Mission Institute of the Romanian Orthodox Church, 2006

[34] Nin, M., Ufficiatura bizantina. La Liturgia delle ore nella tradizione bizantina, Roma, Dispense Pontificio Istituto Orientale, 2002-2003

[35] Omont, H., Inventaire sommaire des manuscrits grecs de la Bibliothèque nationale, Troisième partie: Ancien fonds grec, codd. 2542-3117. Coislin. Supplément grec. Autres bibliothèques de Paris. Départements, Paris, Libraire Alphonse Picard, 1888

[36] Parpulov, Georgi R., Toward a History of Byzantine Psalters, ca. 850-1350 AD, Plovdiv, 2014

[37] Pidalion (reprinted), Neamţ Monastery, 1844

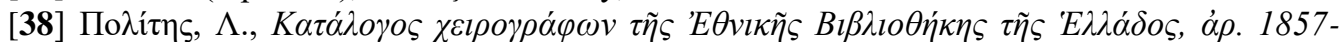
2500, А $\theta \tilde{\eta} v \alpha 1,1991$

[39] Pott, Thomas, La réforme liturgique byzantine. Étude du phénomène de l'évolution nonspontanée de la liturgie byzantine, in Bibliotheca Ephemerides Liturgicae Subsidia 104, Roma, Centro Liturgico Vincenziano - Edizioni Liturgiche, 2000

[40] Pott, Thomas, Réforme monastique et évolution liturgique. La réforme stoudite, in Crossroad of cultures. Studies in Liturgy and Patristics in Honor of Gabriele Winkler, edited by Hans-Jürgen Feulner, Elena Velkovska and Robert F. Taft, in Orientalia Christiana Analecta 260, Roma, Pontificio Istituto Orientale, 2000, pp. 557-589

[41] Preda, N., Aşa-numitele "rugăciuni ale catismelor" potrivit Codicelui Ateniense 2478: studiu de liturgică (The So-called "Prayers of the Kathismata" according to Codex Ateniense 2478: Liturgical Study). Degree Paper, Bucharest, Granada Publishing, 2016

[42] Preda, N., Preghiere salmiche di autori vari secondo il codice "Vaticano Greco 783" (ff. 1-96r). Doctoral thesis, Bucharest, Granada Publishing, 2016

[43] Pruteanu, Hierom. PhD Petru, "Evoluţia Rânduielilor tipiconale în Răsăritul ortodox. Studiu istorico liturgic" (The Evolution of the Typikon in the Orthodox East. Liturgical Historical Study), in Studii Teologice, Third Series, Year II, No. 1 (2006), pp. 63-99

[44] Psaltirea Prorocului și Impăratului David (Psalter of the Prophet and Emperor David), Bucharest, 2016 
[45] Salmon, P., Les “Tituli Psalmorum” des manuscrits latins, Études Liturgiques 3, Paris, Cerf, 1959

[46] Sartore, D., A. M. Triacca and C. Cibien, Liturgia, Milano, Edizioni San Paolo, 2001

[47] Sfântul Simeon Arhiepiscopul Tesalonicului, Tratat asupra tuturor dogmelor credinţei noastre ortodoxe, după principii puse de Domnul nostru Iisus Hristos şi urmaşii Săi (Saint Simeon Archbishop of Thessalonica, Treaty on all the Dogmas of our Orthodox Faith, according to the Principles of Our Lord Jesus Christ and His Followers). Volume II, in the Colection "From the Beauties of Christian Living" 2, Suceava, Publishing House of Suceava and Rădăuţi Archbishopric, 2003

[48] Strunk, O., "The Byzantine Office at Hagia Sophia", in Dumbarton Oaks Papers 9-10 (1956), pp. 175-202

[49] Taft, R. F., A partire dalla liturgia. Perché è la liturgia che fa la Chiesa, Roma, Edizioni Lipa, 2004

[50] Taft, Robert F., La liturgia delle ore in oriente e occidente. Le origini dell'ufficio divino e il suo significato per oggi, Roma, Edizioni Lipa, 2001

[51] Taft, R., "Mount Athos: A Late Chapter in the History of the "Byzantine Rite", in Dumbarton Oaks Papers 42 (1988), pp. 179-194

[52] Taft, R. F., O Istorie a Liturghiei Sfântului Ioan Gură de Aur. Volumul II. Transferul darurilor și celelalte rituri preanaforale. Partea 1. Intrarea cea Mare (A History of the Divine Liturgy of Saint John Chrysostom. Volume II. Transfer of Gifts and Other Pre-anaphoral Rites, Part 1. The Great Entrance). $2^{\text {nd }}$ Edition Revised. Translation and preface by Cezar Login, Cluj-Napoca, Renașterea Publishing, 2014

[53] The Codex Alexandrinus (Royal MS. 1 D. V-VIII), in reduced photographic facsimile. Old Testament, part IV. I Esdras-Ecclesiasticus, London, 1957

[54] Triodion which includes church services from the Sunday of the Publican and Pharisee until the Holy Saturday, Bucharest, Publishing House of the Bible and Mission Institute of the Romanian Orthodox Church, 2010

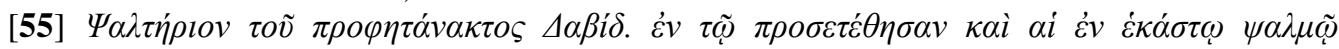

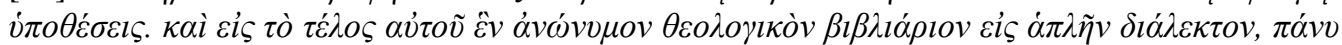

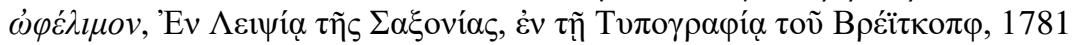

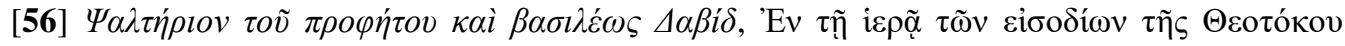

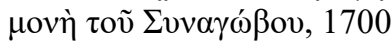

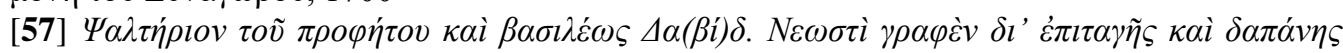

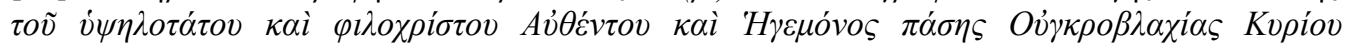

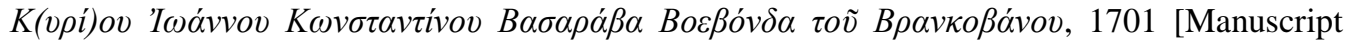
from Iași Metropolitan Library, Fond HH Teoctist, No. 12] 